\title{
INVASION OF THE CANADIAN PRAIRIES BY AN EXOTIC PERENNIA
}

J.T. ROMO and P.L. GRILZ, Department of Crop Science and Plant Ecolc University of Saskatchewan, Saskatoon, Saskatchewan, S7N OW0 and E.A. DRII Canadian Wildlife Service, 115 Perimeter Road, Saskatoon, Saskatchewan. S7N

\section{Introduction}

Since settlement of the Canadian Prairies the grasslands have been influenced by a variety of agricultural practices. ${ }^{18}$ These practices and their impact, such as tillage and growing annual crops, have completely obliterated the grasslands. Another activity that has generated much interest and has modified the prairie is imprudent grazing management. While these activities have drawn considerable attention from conservationists, an equally important event which has received less attention been the purposeful introduction of otic plants such as Alfalfa (Medic o sativa), Crested Wheatgrass (Agrogy $n$ cristatum), Russian Wild Rye (Psathy tachys juncea) and Smooth Brc (Bromus inermis) into the prairie eco tem, primarily for the purpose of for production.

To the uninformed or unconcerned e introduction of exotic species into ecological integrity of the prairie eco

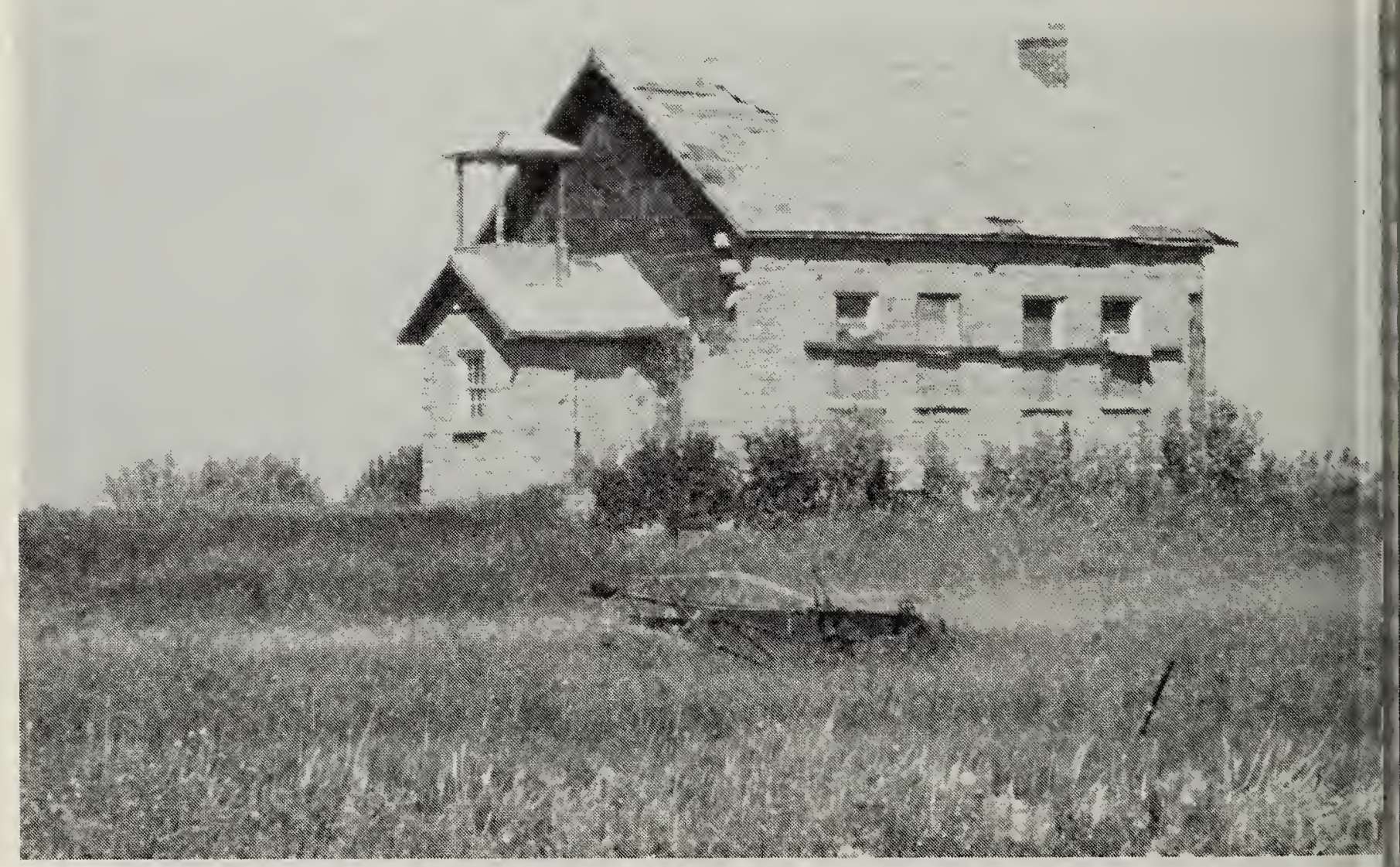

Old school north of Maryfield, Saskatchewan. Abandoned building sites often vegetated with Smooth Brome, which moves outwards from these sites. 
ms is viewed as harmless unless they ose a threat to crops. However, to conrvationists these introductions should cnal the potential for further destruction native flora and, they also signal an aknown threat to the ecosystem. Unfornately many students of the natural airie have been concerned with the rger and more obvious issues, cultivaon and grazing, not to grassland disaparance because of seeding and the itive expansion of exotic species.

How long and in what ways these exc plants express their potential and imct on the ecosystem over their new he is not elucidated by short-term aluations. Their dispersal, estabiment, and domination of native flora be an insidious process that for all actical purposes permanently transms native vegetation into plant cominities dominated by exotics. In ticular, many vegetation complexes becoming dominated by Smooth ime.

\section{e introduction and use of Smooth ome}

he exact date when Smooth Brome s introduced to Canada is not known, it appeared sometime between 1875 4 1888. ${ }^{15} \mathrm{Immigrants}$ from Europe may e brought some of the grass with them which there will be no record. Regardof the date of introduction and its gin, by 1896 scientists with the minion Department of Agriculture gnized Smooth Brome as a useful ss for revegetating native grasslands had become "exhausted;" by 1930 its erior adaptability and performance recognized.' It became widely used hay and pasture, frequently escaping ivation to form a common grass cover roadsides, railway rights-of-way, ndoned lands, and other disturbed $15 .{ }^{10}$ Since its introduction in the late Os Smooth Brome has been widely ibuted throughout Canada.
This long-lived perennial is adapted to a variety of soils, growing best on those that are fertile and well-drained. ${ }^{16}$ Smooth Brome is valued for grazing and hay and it is the most important introduced forage in the central and northern parts of the Prairie Provinces." This distribution corresponds with the Aspen Parkland and the southern edge of the Boreal Forest. In the Mixed Prairie Smooth Brome is best adapted to sites that are cooler and moister than the general environment. It is also grown under irrigation.

\section{Ecological relations of Smooth Brome with native flora and fauna}

Once Smooth Brome establishes, it effectively suppresses the growth of other species. Research on a protected Fescue Prairie in Saskatchewan identified that the richness of native species declined to a point where native species were almost non-existent on sites where Smooth Brome had invaded (Grilz, unpubl. data). Where exotic species were dominant in Mixed Prairie in Manitoba, the cover and diversity of native species was reduced. ${ }^{22}$ Wilson concluded that introduced species can competitively exclude native grasses, with Smooth Brome being one of the most dominating introductions. ${ }^{23}$ Looman also noted a decline in floristic composition on sites where Smooth Brome had invaded."

Not only is this demise and domination of native species occurring, but the adulteration of native germplasm is also a concern. There is evidence that Smooth Brome is crossing and intergrading with Northern Awnless Brome (Bromus pumpellianus), a native perennial (V. Harms, pers. comm.). What long-term impact this will have is unknown.

Associated with the increases in Smooth Brome in native prairie is a decline in use of the grassland by many species of wildlife (Driver, unpubl. data). At Last Mountain Lake Wildlife Refuge Driver found that as the age of Smooth 
Brome-dominated grasslands increased the use by birds declined from eight to ten species to primarily two species Savannah Sparrow and Clay-colored Sparrow. Wilson and Belcher concluded that exotic vegetation influences bird communities by causing a change in the species composition with some bird species increasing while others decline. ${ }^{22}$

\section{Dispersal Ecology of Smooth Brome}

The most obvious threat by Smooth Brome to native grassland ecosystems is the cultivation and seeding of this exotic on prairie that has been degraded by improper grazing. Other threats are subtle, but perhaps more important is the spatial distribution of this species.

In the early evaluations of this grass, Fletcher stated that Smooth Brome had one disadvantage - "a habit of growing like quackgrass" (presumably Agropyron repens). ${ }^{5}$ We can only speculate exactly what was meant by this statement, but it is assumed he meant that Smooth Brome possessed an aggressive and spreading habit. Smooth Brome is one of the best grasses for erosion control, thus it is often seeded on sites disturbed in road construction, and oil, gas and mineral development. ${ }^{21}$ These many seedings act as small foci that can collectively occupy nearby areas faster than one large introduction such as seeded pastures. ${ }^{6}{ }^{9}$ Hume and Archibold's data show that seeds of Smooth Brome were transported at least $7 \mathrm{~m}$ from the edges of seeded pastures. ${ }^{9}$ Provided a suitable habitat is present in adjacent vegetation, many sites are subject to invasion because of prolific seed production. Once established Smooth Brome spreads rapidly by rhizomes and seeds. Thus, the well-intentioned effort of stabilizing sites by revegetating them with Smooth Brome is actually accelerating the spread of this species.

The major issue that must be reckoned with is the planting of Smooth Brome in the vicinity of grasslands that are suscep- tible to invasion. How it moves into through the prairie does not appeai lated to a specific vector, but rather host of dispersal mechanisms.

Looman concluded that Smooth $\mathrm{Br}$ does well in the Fescue grasslanc Canada, invading sites that are graze otherwise disturbed." However, Fes Prairie which is protected form grazin domestic livestock is not exempt $f$ invasion by Smooth Brome. Data fro relict Fescue Prairie near Saskat shows that Smooth Brome was the most common of 16 graminoids. Sim ly, Blood reported that Smooth Brc was the fifth highest producing gramir in Fescue Prairie in Riding Mountain tional Park. ${ }^{2}$ In relative terms both of th tracts of Fescue Prairie were undisturt We have also observed brome invac many relict areas of Fescue Prairie.

The grasslands of the Mixed Pra region in southern portions of the Pra Provinces appear resistant to invasior Smooth Brome. However sites with br soil and moisture conditions, incluc riparian zones and wooded draws, being invaded by brome.

Native grasslands that are protected viewed by many naturalists as being disturbed, however, this attitude tempered by the definition of disturba and its scale. Large accumulations dead plant material tend to reduce vigour and density of the grasses, crea sites amenable to establishment of of species. Ways of preventing this cumulation include its removal by g ing or mowing and the use of prescri burning. ${ }^{4}$ Hulbert concluded that wh fire is used regularly Smooth Brome is I in native grassland except where na grasses have been weakened or are sent following disturbance. ${ }^{8}$

Protected native grasslands may harbour high populations of mamn and their activities such as burrowing 
rbivory can create significant disturince on a localized scale that is not pvious. Larger disturbances are also used by burrowing animals such as Red $x$ and Badger. We have observed Thiren-lined Ground Squirrels caching inrescences of Smooth Brome near their rrows. This caching, combined with disturbance of burrowing creates a tential site for establishment.

We have a poor understanding of the portance of this species in the diets of ds. For a similar species, Cheatgrass ome (Bromus tectorum), a small perhtage of the seeds ingested can pass harmed through the digestive tract of ds. ${ }^{19}$ Perhaps another important means dispersal is the fact that often this grass hayed after seeds have been formed. en this hay is consumed by domestic stock and native ungulates some ds may pass through the digestive tract a germinable condition and be dissed over the landscape.

mooth Brome has a prolonged period eed dispersal, with seeds being dissed from maturation in mid-summer ughout the winter (V. Harms, W.P. ser Herbarium, University of Saschewan). Since seedheads are often ated above the snow, seeds may be wn from established plants across w pack, lodging at other sites in the $w$. It is a matter of chance as to ther the site of seed deposition vides a suitable safe site for its geration and establishment.

nooth Brome is often planted along ams because of the high potential for ge production on these sites. Since is and seedlings of Smooth Brome can tolerate prolonged periods of floodthe seeds can be transported nstream and deposited over a wide ${ }^{14}$ The movement of seeds by water ese situations is extremely important ts long distance dispersal along rian zones, although the other transport mechanisms are probably also operating.

\section{Why is Smooth Brome successful?}

This question can not be answered with certainty, but from a theoretical standpoint the following arguments can be put forth. This grass has been selected by forage breeders for superior establishment, growth, persistence, and prolific seed production over a wide range of conditions. The germination and the growth of seedlings are also far superior to many native species. ${ }^{20}$ When established brome forms a dense root system in the upper soil profile. ${ }^{13}$ The purposeful selection for the prevailing environmental conditions of the Canadian Prairies and natural selection processes have produced an extremely well-adapted species that has become naturalized. These characteristics, combined with the fact that there are few if any natural predators, are enabling the grass to spread unchecked.

\section{What does the future hold?}

Through the history of settlement on the Canadian Prairies there has been an attitude of attempting to remedy the symptoms of poor land management rather than addressing the cause(s). One of these ill-founded solutions has been the introduction of exotic plants. Smooth Brome was examined as a potential forage because production of native grasses was apparently declining. ' Little or no attempt was made to determine why it was declining. This attitude was, and still is, bolstered by the thought that technology or new technologies will permanently solve resource management problems.

Conservationists have the opportunity to learn from the mistakes made by treating symptoms of poor resource management rather than identifying and treating the cause of the problems. The invasion and domination by Smooth Brome of natural ecosystems, a serious resource management problem, must be ad- 
dressed and solved before the natural heritage of the Canadian Prairies is lost. This issue will continue to worsen because of natural selection pressures and the release of new and improved varieties.

Today we do not know for certain what the longterm consequences of introducing Smooth Brome might be. Only time will elucidate the implications of introducing this species to native plant communities. However, by examining the impacts of this plant on a local scale we feel confident of some predictions.

It is our opinion that a passive or handsoff approach to managing natural areas will eventually result in invasion by this exotic. Vegetation types that appear most prone to invasion by Smooth Brome are Boreal Forest, Aspen Parkland, Fescue Prairie and specialized habitats occupied by woody species in the Mixed Prairie. These vegetation types provide habitats that are similar to the "steppe meadows," shrubbery and openings that Smooth Brome occupies in Eurasia. ${ }^{2}$ Conservation management plans must be developed that place managers in a proactive position rather than one in which they react to invasions. The consequences of invasions by Smooth Brome will become more severe the longer the development of plans is delayed.

\section{Conclusions}

The future of many native plant communities on the Canadian Prairies is bleak because of the combined influence of ploughing native grasslands and the introduction of Smooth Brome. As more land comes under cultivation and the native grasslands become more fragmented, the ratio of the disturbed land to undisturbed prairie increases. This increase in the relative amount of disturbed land will accelerate the rate of spread of exotic species.
Conservationists are now faced wit enormous task if they wish to preserve integrity of native flora. Our na grassland ecosystems are threatened land use philosophy and a species was introduced without considering long-term impact on the ecosyst Should we accept Smooth Brome as of the native flora and let this species its natural course? How much and wh is this species acceptable? These qr tions can be answered only a landscape management goals are es lished.

We should prevent invasions where invasions have already occur the species must be controlled in the liest stages of development. In of words, strategies should be developer protect the unaffected or least affec grasslands first. Until this is completer must direct our management activi toward eliminating satellite populatic This will require that we expand our derstanding of ecological relationship Smooth Brome in native communitie:

1 BEST, K., J. LOOMAN and CAMPBELL. 1971. Prairie gras identified and described by vegeta characters. Agric. Canada Publ. 1413. tawa.

2 BLOOD, D.A. 1966. The Fest scabrella Association in Riding Moun National Park, Manitoba. Can. Field-Nc 80:24-32.

${ }^{3}$ CROSSON, P.R. and N.J. ROSENBE 1989 Strategies for agriculture. Scier Amer. 261:128-135.

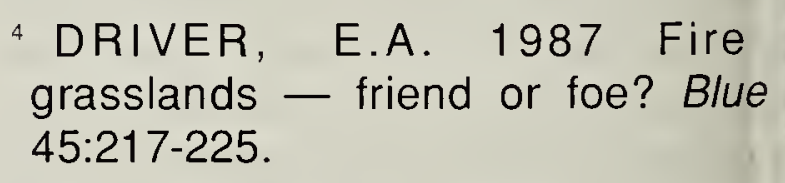
grasslands - friend or foe? Blue 45:217-225.

${ }^{5}$ FLETCHER, J. 1893 A valua European grass. Canada House of $\mathrm{C}$ mons Report of the Select Standing C mittee on agriculture and colonizatior 32. 
HARPER, J.L. 1977. Population biolgy of plants. Academic Press, N.Y.

HEINRICHS, D.H. 1969. Forage rops research, past, present and future. In IIELSON, K.F., Ed. Proc. of the anadian Forage Crops Symposium. pp 3-67. Modern Press, Saskatoon.

HULBERT, L.C. 1986. Fire effects on allgrass prairie. In CLAMBEY, G.K. and .H. PEMBLE, Eds. Proc. of the ninth orth American prairie conference. pp 13842. Tri-college University Center for Enronmental Studies, North Dakota State niv., Fargo.

HUME,L. and W. ARCHIBOLD. 1986. he influence of weedy plant habitat on the ed bank of an adjacent cultivated field. an.J. Bot. 64:1879-1883.

NOWLES, R.P. and W.J. WHITE. 1949. e performance of southern strains of ome grass in western Canada. Sci. Agric. :437-450.

OMAN, J. 1969. The fescue asslands of western Canada. Vegetatio :128-145.

DOMAN, J. 1983. Productivity of peranent bromegrass pastures in the rklands of the Prairie Provinces. Can. J. ant Sci. 56:829-835.

DOMAN,J. 1983. 111 range and age plants of the Canadian prairies. ric. Canada Publ. 1751. Ottawa.

KENZIE, R.E. 1951. The ability of gige plants to survive early spring floodSci. Agric. 31:358-367.

DODY, M.E. and R.N. MACK. 1988. ntrolling the spread of plant invasions: importance of nascent foci. J. Appl. plogy 25:1009-1021.

WELL, L.C. 1973. Smooth megrass. In Forages: the science of ssland agriculture. pp 254-262. lowa te Univ. Press, Ames.
17 PYLYPEC, B. 1986. The Kernen Prairie - a relict fescue grassland near Saskatoon, Saskatchewan. Blue Jay 44:222-231.

18 ROWE, J.S. 1987. One hundred years of land use. Blue Jay 45:127-139.

19 SAVAGE, D.E., J.A. YOUNG and R.A. EVANS. 1969 Utilization of medusahead and downy brome caryopses by chukar partridges. J. Wildl. Mgmt. 33:975-978.

20 SMOLIAK, S. and A. JOHNSTON. 1968. Germination and early root growth of grasses at four root-zone temperatures. Can. J. Plant Sci. 48:119-127.

21 WALTON, P.D. 1983. Production and management of cultivated forages. Reston Publ. Reston, Virginia.

22 WILSON, S.D. and J.W. BELCHER. 1989. Plant and bird communities of native prairie and introduced Eurasian vegetation in Manitoba, Canada. Cons. Biol. 3:39-44.

${ }^{23}$ WILSON, S.D. 1989. The suppression of native prairie by alien species introduced for revegetation. Landscape Urban Plann. 17:113-119.

\section{EDITOR'S NOTE:}

The problem with Smooth Brome is that its natural insect, nematode, and fungous pests haven't come over with it from Europe. And this raises a taxonomic question in my mind: If Bromus inermis is akin enough to B. pumpellianus to cross with it, why can't the parasites and predators which $B$. pumpellianus, as a native species, undoubtedly bears as a burden, attack $B$. inermis? I haven't observed any such disease or insect attack in nature; therefore my guess is that the two species are distinct, contrary to the views given by some authors. - J.H. Hudson 